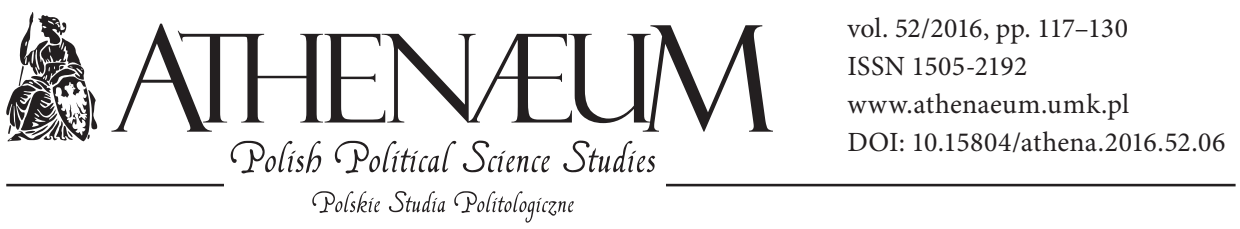

\title{
THE REPUBLIC OF GEORGIA IN THE FACE OF A CRISIS: THE EFFECTIVENESS OF EXTERNAL ACTIVITIES
}

\author{
REPUBLIKA GRUZJI W OBLICZU KRYZYSU. \\ SKUTECZNOŚĆ DZIAŁAŃ ZEWNĘTRZNYCH
}

Joanna Piechowiak-Lamparska*

\begin{abstract}
The problem of effectiveness of reaction to external crisis expressed by participants of the international system is very much a live issue. In view of growing military conflicts in many parts of the world, the question how effective the relations between the players are in the international arena is a category worth analysing. This article concerns the Russian-Georgian crisis, whose most important manifestation was the military conflict in August 2008 and most significant result - the loss of Georgia's territorial integrity and the strengthening of Russia's position in the post-Soviet area. The analysis, conducted according to the presented scheme, focused on the effectiveness of external activities undertaken by the Republic of Georgia in the face of the Moscow-Tbilisi crisis.
\end{abstract}

Keywords: international crisis, effectiveness of external activities, Georgia, Russia, RussianGeorgian relations, 2008 August war

\section{ABSTRAKT}

Problem skuteczności reakcji uczestników systemu międzynarodowego na kryzys zewnętrzny jest kwestią bardzo aktualną. Z uwagi na pogłębiające się konflikty zbrojne $\mathrm{w}$ wielu rejonach świata kwestia skuteczności powiązań istniejących pomiędzy graczami na arenie międzynarodowej jest wartą analizy kategorią. Artykuł ten dotyczy kryzysu rosyjsko-gruzińskiego, którego najważniejszą emanacją był konflikt militarny w sierpniu 2008 roku, a najistotniejszym skutkiem - utrata integralności terytorialnej przez Gruzję oraz wzmocnienie pozycji Rosji na obszarze poradzieckim. Analizie przeprowadzonej według zaprezentowanego schematu podlegała skuteczność działań zewnętrznych Republiki Gruzji w obliczu kryzysu na linii Moskwa-Tbilisi.

Słowa kluczowe: kryzys międzynarodowy, skuteczność działań zewnętrznych, Gruzja, Rosja, stosunki rosyjsko-gruzińskie, wojna sierpniowa 2008

\footnotetext{
* Nicolaus Copernicus University, Faculty of Political Sciences and International Studies.
} 


\section{INTRODUCTION. CAN STRATEGY PREPARE WELL FOR A CRISIS?}

In the $21^{\text {st }}$ century, crisis seems to be a phenomenon omnipresent in the international sphere. The analysis which targets the overall emergence of crises in the world may lead to surprising conclusions: the world is tormented by serious problems which, in a short time, can turn into a crisis, that is, a turning point that endangers the international order. However, states, as principal actors of the international stage, have lost monopoly on crisis (see Kącka, 2012, p. 131-145). The increasing importance and institutionalisation of some international organizations, such as NATO, the EU, or ASEAN, made their internal and external problems more substantial.

The category of international crisis has undergone a significant redefinition. At present, crisis is not perceived solely as a situation so serious that there is a high probability of war or military conflict (vide Brecher, 1977, p. 39-74), but also as a set of various threats: political, social, economic (vide Walter, 2016, p. 289-312; du Plessis, Freytag, Boshoff, 2015, p. 17-36), migratory (vide Odutayo, 2016, p. 365-379), religious, cultural, and civilisational, which may result in another radical solution. Perhaps crisis is defined even too broadly since every case of destabilisation can now be called a crisis (vide Cohen, 1979; North, 1963; Lebow, 1984; McClelland, 1961, p. 182-204; Burton, 1984). The examples of crises which have been getting a lot of publicity are the economic crisis caused by the instability of financial markets, the migration crisis provoked by the uncontrolled influx of refugees to Europe mostly from Syria and Afghanistan, the conflict in Ukraine, which resulted in Russia's annexation of Crimea, or the Russian-Georgian conflict, after which two separatist provinces - Abkhazia and South Ossetia - declared independence from Georgia. It seems that it is not even possible to name and summarize the crises which have taken place only in the last decade.

It should be emphasized that the article focuses on the analysis of only one type of crisis, that is, an international crisis, which results from a conflict between two sovereign states. The case study analysed here concerns the narrowly understood Russian-Georgian crisis ${ }^{1}$, which in August 2008 turned into a con-

1 The Russian-Georgian crisis, whose result was the military conflict in August 2008, could be analysed also broadly as a set of historical, political, geostrategic, economic and social causes that 
flict of military character, and whose most important consequences included Georgia's loss of its territorial integrity (vide Rondeli, 2014, p. 35-48; Tsereteli, 2014, p. 74-93; Piechowiak-Lamparska, 2013, p. 419-436; Boesen, Larsen, 2012, p. 102-121; Materski, 2010, p. 362-375; Bryc, 2009, p. 65-76). The analysis shall consider the effectiveness of external activities undertaken by Georgia in order to handle the crisis. Therefore, the foreign policy activities (and their results) discussed here shall encompass those that happened in the period lasting from the beginning of the Immediate Response-2008 military manoeuvres which took place on the Georgian territory as a part of the Partnership for Peace Programme and the Russian Caucasus Frontier 2008 manoeuvres in North Ossetia until the European Union Monitoring Mission in Georgia (EUMM) commenced its operations.

It is not easy to assess the effectiveness of the foreign policy of a state. For this reason, it seems that such effectiveness can be relatively most thoroughly analysed and assessed at a specific level of such policy. For instance, strategic goals declared in the long-term perspective can be compared with results achieved over an analogous time span. This article addresses the question of effectiveness of state's external reaction to a crisis and therefore it analyses the external effectiveness of attaining ad hoc goals.

The process of assessing the effectiveness of external activities during a crisis is multistage (Fig. 1). In order to perform an effectiveness analysis, it is necessary to define the stage of establishing foreign policy goals of a state; in other words, to analyse the strategy of foreign policy and security in the context of predicting sudden threats along with the existing possible crisis areas. The following stage includes defining a crisis, establishing its scope and time frames. Next, it is important to determine available methods and means of reaction as well as to assess if the principles of a strategy have been fulfilled. The last stage is focused on evaluating the effectiveness of the undertaken external activities. To sum up, it needs to be assessed if a state has achieved its goals when attempting to handle a crisis, that is, to say whether it has been effective.

In order to analyse and assess the effectiveness of external activities in the face of a crisis, two types of analytical scheme can be applied: 1) the analysis of a crisis based on the assessment of every single event, its results, possibilities 

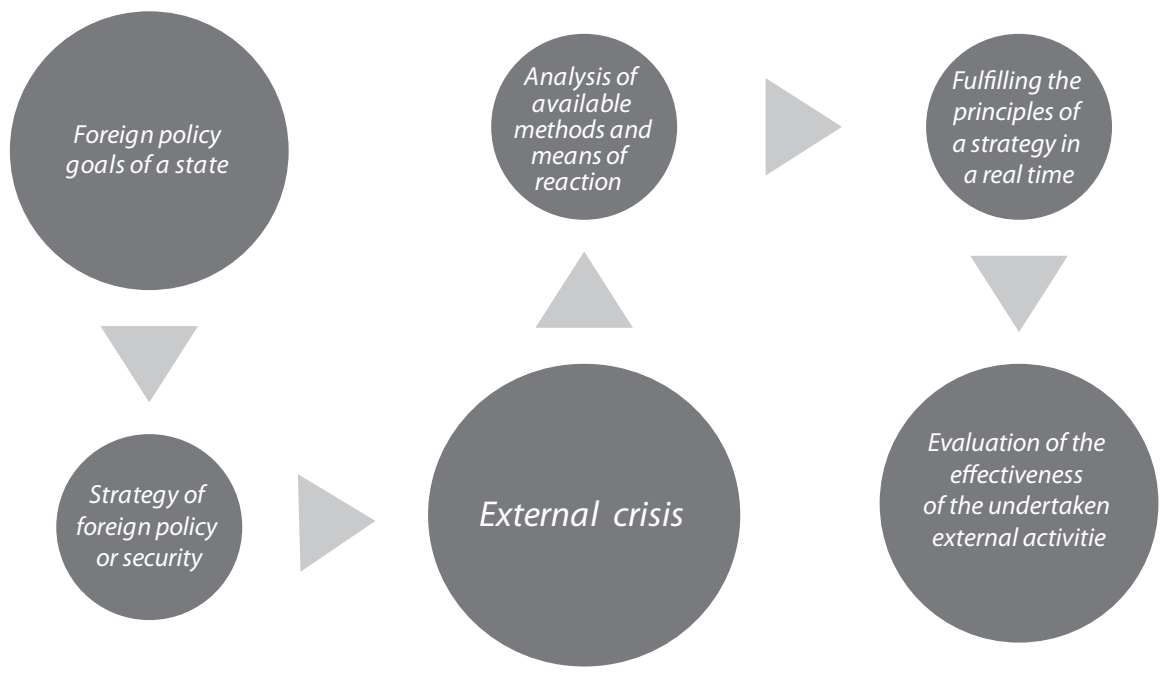

Fig. 1. The process of assessing the effectiveness of external activities during a crisis Source: Own work.

to counteract or respond, and the goals achieved by external actions, or 2) the status quo analysis of the situation after a crisis based on establishing the actual state and collecting data on the set goals, available means and their effects. In the research on the effectiveness of Georgia's external activities in the face of a crisis, the scheme which does not require a detailed analysis of events has been applied.

\section{THE RUSSIAN-GEORGIAN CRISIS IN 2008. A LITTLE CRISIS THAT SHOOK THE WORLD²}

The Russian-Georgian crisis has its roots in the beginnings of the Georgian state. However, nowadays, in order to understand clearly the geopolitical situation, it is sufficient to look at the map of the South Caucasus. From the ethnical point of view, Georgia is inhabited by 12 nations and ethnic groups, which in itself may serve as a background for a conflict at any time. The largest group are Georgians (86.8\%), followed by Azerbaijanis (6.3\%), Armenians (4.5\%), Russians (0.7\%), Ossetians (0.4\%), Yezidis (0.3\%), Kists (0.2\%), Greeks (0.1\%), and Assyrians

2 It is a paraphrase of a book title by Ronald D. Asmus, A Little War that Shook the World (2010). 
(0.1\%) (GEOSTAT, 2016). Among Georgians there are also Svans, Megrelians, Abkhazians, and Adjarians, which only intensifies internal divisions. Therefore, the reasons for the August war are not limited only to the issues concerning the relationship between Moscow and Tbilisi, but they also include the frozen internal conflicts in Abkhazia and South Ossetia. Separatist aspirations of both provinces supported by the activities of the Russian Federation as well as the none too flexible policy of Mikheil Saakashvili's administration led to a gradually increasing conflict.

The August war shook the international order in the post-Soviet territory. In the region of the South Caucasus, there are a lot of players with different interests who invest their reserves and resources to varying degrees. Agnieszka Bryc (2011, p. 108) thinks that "the states which determine the balance of power in the postSoviet space are the Russian Federation, the United States, China, and Iran. While for Russia the post-Soviet territory constitutes 'the near abroad', or their sphere of influence, for the USA, China, and Iran the republics of the former Soviet Union are the sphere of interest. This difference means that Moscow is capable of taking military actions to defend its sphere of influence against the growing engagement of third countries". However, despite the fact that the main participants of the crisis were Georgia, Russia, separatist Abkhazia, and South Ossetia, the conflict also engaged intergovernmental organizations of international character (IGO), such as the EU and NATO, as well as certain states - particularly the USA, France, Turkey, Poland, and the Baltic countries.

Yet, the analysis of who gained the most will not give a simple answer. Here, Strobe Talbott's dissent seems to be particularly appropriate as he said that "the big conclusion that Ron [Asmus] draws from the 'little war' of his title is that it had no winners and multiple losers" (Asmus, 2010, p. vii). Consequently, it is difficult to name the one player who gained the most from the crisis. Georgia appears to have lost the most since its territorial integrity was violated and as a result the state delayed, or even ruined, its accession process to the EU or NATO. And what did Georgia gain? One might venture an opinion that the country gained a reputation of a reckless state as well as it gained knowledge of its allies and their loyalty in the face of a real danger, whereas president Mikheil Saakashvili partly lost his credibility as a leader of the Georgian nation. Abkhazia and South Ossetia also gained not too much as they are not sovereign countries, and thus are not recognized by the majority of states and international organizations, but they are elements of Russia's game and they depend on Russia in many respects. What the final balance of gains and losses for Russia was is not clear either. It should be 
noted that although the Russian Federation kept its buffer zone, it achieved that at the expense of a military conflict, the EU sanctions, and worsening its relations with NATO. The organizations - NATO and the EU - also lost Georgia, their relatively most reliable ally in the region of the South Caucasus, since the state's aspirations to deepen the process of integration were questioned, which resulted from the fact that Georgia's role in the conflict was not explicit - the state was not just a passive victim attacked by immensely stronger Russia.

But why did the relatively small crisis shake the world? Ronald D. Asmus (2010, p. 215) assesses the outcome of the Russian-Georgian crisis as a certain kind of test failed by all participants of the conflict. "The Russo-Georgian war of August 2008 was a little war that shook the world. It shocked a West that had become complacent in its belief that war in Europe had become a thing of the past and thus ignored the warning signs that conflict was brewing between Moscow and Tbilisi. [...] Perhaps most importantly, this war violated several core principles of what was supposed to be a new European security order, thus raising questions about its future. As a result, this little war shook the belief that a democratic and cooperative peace had triumphed in Europe twenty years after the Iron Curtain fell and that the kind of geopolitical competition and spheres of influence thinking that had produced so much conflict and bloodshed in the continent's past had been banished". In the light of the events present in the international arena (for example, the conflict in Ukraine and the annexation of Crimea), it seems that Asmus might have been right.

\section{EXTERNAL ACTIVITIES AS A RESPONSE TO THE CONFLICT: TEST OF PARTNERSHIP, TEST OF INTERESTS}

Was Georgia effective in handling the conflict, which on the one hand affected the country, but on the other hand was provoked by the state itself? More precisely - was the recklessness profitable? In order to assess the effectiveness of Georgia's foreign policy during the period in question, it is necessary to analyse the key goals and verify whether they were reached. The goals of Georgian foreign policy were taken from documents of strategic character and were verified with the method of content analysis (the analysed texts included international law documents, security and foreign policy strategies, declarations issued by states and international organizations; moreover, the analysis involved the course of events). Intuitively, both in life and in international politics, we initially check 
if our alliances function in the face of a real crisis. This is a kind of test whether a strategic partnership or any other unique relationship is valuable or merely a theatre of empty words and gestures.

\section{Main Principles in Strategic Documents}

The first document on security and foreign policy in the Republic of Georgia was the National Security Concept of Georgia. It was the first act of such importance passed by the Parliament of Georgia since the Rose Revolution and the longest binding strategy of such a broad scope. The document was published in 2005 and was in effect until 2012, when it was substituted by a new version.

The strategy assumed already in its introduction that the primary goal of the state's activity is its survival and security; therefore, it determined the national interest in the understanding suggested by neoliberal concepts. It was emphasized that Georgia would defend its most important interests using all the means and methods allowed by the law. The main values which governed the state's activities in the following years were: 1 ) independence (understood as respecting their own as well as other states' sovereignty),2) freedom (understood as rights and freedoms provided for in international conventions), 3) democracy and the rule of law (understood as establishing and maintaining a system of democratic governance and the separation of powers), 4) prosperity (understood as a balanced and prosperous economic development of a country and its citizens), 5 ) peace (understood as a continuation of friendly relations in the international system), 6) security (understood as providing security and territorial integrity).

There are several goals which could be connected with the crisis in August 2008. First of all, these were the goals of promoting the national interest, such as: guaranteeing territorial integrity and national unity, ensuring stability in the region of the South Caucasus, enhancing democracy and peace in the neighbouring countries and providing energy security. The strategy also defined the most important threats, such as: violating territorial integrity by separatist movements, side effects of conflicts with the neighbouring countries, a foreign military intervention and the military presence of the Russian Federation on the Georgian territory. The foreign policy goals included mostly: strategic partnership with the USA, Ukraine, Turkey, Armenia, and Azerbaijan; partnership with the Russian Federation; accession to the EU and NATO and cooperation in the region of the Black Sea (as a part of GUAM, BSEC, BLACKSEAFOR). 
Moreover, the document The Georgian Foreign Policy Strategy for the Years 2006-2009 was the first official regulation on the foreign policy strategy of the Georgian state prepared by the Ministry of Foreign Affairs after the Rose Revolution. Its author was Gela Bezhuashvili, Minister of Foreign Affairs. It includes strategic objectives, medium term tasks and actions. It means that less than three years after regaining sovereignty, the state presented a comprehensively wellthought-out scheme and established a hierarchy of goals.

The strategy perfectly shows the system of elements which are essential for the realization of the national interest, short-term and long-term goals, as well as the state's activity in the international arena. The order in which the elements are placed in the document represents a structure organized - according to their importance, from the highest to the lowest.

The aim of the strategy was to unify the vision of the main trends and detailed priorities of Georgian foreign policy in order to increase the work efficiency of the foreign service and the effectiveness of the state's foreign policy. The adopted mission refers to such tasks as promoting the interests of the Republic of Georgia in the international arena, protecting the rights of Georgian citizens outside the state's borders and improving relations among international communities. Significantly, the mission was to be carried out according to democratic values and respect for the idea of common aspiration to security and prosperity. The consolidation of democracy and enhancement of further social and economic changes were to be consistent with the foreign policy.

The strategic goals were divided into four groups: 1) Independent, Secure and Stable Country, 2) Prosperity and Democracy, 3) Georgia's Role in the International System, and 4) Georgian Citizens Abroad.

The first group of goals, which can be associated with the Russian-Georgian crisis, includes above all: 1) maintaining territorial integrity (inviolability of Georgian borders which are recognized by the international law) together with the implementation of the peace programme in South Ossetia (multilateral cooperation with OSCE and the EU and bilateral cooperation with the USA and the Russian Federation) as well as developing a common peace programme for Abkhazia (cooperation on the UN forum); 2) strengthening the national security system (increasing the state's ability to defend) together with creating favourable conditions for the state's development (active contacts on bilateral and multilateral levels in order to receive external support for sovereignty); 3) strengthening stability in the region of the South Caucasus, together with active use of existing mechanisms of regional cooperation (activity in CDC, 
GUAM, and BSEC) and enhancing cooperation in the Black Sea region (developing a regional programme for cooperation); 4) integration with the European countries and NATO together with sustaining the dynamicity of actions aiming at accession to NATO (the 26 plus 1 discussions), supporting the mechanisms of integration with NATO (aspirations to the Membership Action Plan, MAP), increasing awareness of the issue of integration with NATO among the Georgian society (gaining social support), deepening the relationship with the EU (working towards greater involvement of the EU in Georgia and in the region of the South Caucasus within three years), accepting and implementing the European Neighbourhood Policy (realization of the ENP AP), increasing mutual benefits in relations with the EU (development in the sphere of security, trade, transport, energy, infrastructure, education, and culture).

A great attention was given to defining and setting goals as a part of military relations. In the global scale, the goals were mainly connected with accession to NATO and the EU, but also with increasing the cooperation with the Council of Europe and the OSCE. In the sphere of bilateral relations, the main focus was put on the issue of relations with neighbours, more specifically, on the strategic partnership with Turkey, the withdrawal of Russian military bases from Georgia and the intensification of relations with Azerbaijan and Armenia. The second aspect of bilateral relations concentrated on relations with the European countries, including closer relations with Germany, France, Great Britain, Holland and Greece along with closer relations with Estonia, Latvia, Lithuania, Poland, Romania and Bulgaria, as well as strategic partnership with Ukraine. Moreover, in the field of relations with more distant countries, Georgia assumed that it was good to develop strategic partnership with the USA (the most important direction), but also to build closer relations with China, India, Japan and South Korea as well as to enhance economic cooperation with the Middle Asian countries, especially with Kazakhstan. Additionally, Georgia actively participated in solving problems in the Near East (joined the peacekeeping mission in Iraq).

The ad hoc goals resulting from the crisis caused by the Russian-Georgian military conflict in August 2008, distinguished on the basis of conclusions drawn from the above documents:

1. Winning the conflict with the Russian Federation in August 2008;

2. Regaining territorial integrity. 


\section{Implementation of Principles During a Crisis}

The analysis shall not include a detailed account of the Five-Day War and its direct results. This issue was broadly covered in the source literature (vide Fawn, Nalbandov, 2012, p. 57-89; Allison, 2009, p. 173-200; Trenin, 2012, p. 257-269; Mouritzen, Wivel, 2012; King, 2008, p. 2-11). It is important to present the direct result of the conflict and the means of external influence at the disposal of the Georgian diplomacy in the time of the Moscow-Tbilisi crisis. The most important issue was the military conflict, i.e., the Russian troops entering the Georgian territory, and in consequence, separating the provinces of Abkhazia and South Ossetia - making them the de facto Russian satellites (dependent on the military, economic and political help from Moscow). These issues should be treated separately, despite the fact that one is the consequence of the other.

The main strategic principle of Georgia in August 2008 was to keep its territorial integrity and restore constitutional order. President Mikheil Saakashvili believed that such tools as strategic partnership with NATO, the EU and the USA, as well as good relations with the states from their region, Armenia and Azerbaijan, would serve as sufficient protection against a Russian military attack. However, perhaps as a result of provocation or wrongly-calculated actions, it was Georgia who started the artillery assault on Tskhinvali. In consequence, "the Russian peacekeeping forces" took a series of military actions after which, within a few days, the Russian troops had taken control over South Ossetia and started supporting the military operation in Abkhazia. None of the Georgian strategic partners provided Georgia with military or logistic support (the media only informed that the Georgian army got access to American intelligence data; however, the information was not confirmed).

The European Union acted as a mediator between Russia and Georgia and initiated peace negotiations which were conducted with the presence of the Russian President Dmitry Medvedev and Nicolas Sarkozy, who acted as the President-in-Office of the European Union. The 6-point plan, known as the Sarkozy-Medvedev agreement, was also signed by the South Ossetian President Eduard Kokoity and the Abkhaz President Sergei Bagapsh, as well as by Mikheil Saakashvili. Georgia claimed, however, that the Russians had not withdrawn their troops and that they were still conducting the military operation (vide Whitman, Wolff, 2010, p. 87-107; Parmentier, 2009, p. 49-61). In order to express the support for Georgia, the presidents of Poland, Lithuania, Estonia, Ukraine, and the prime minister of Latvia (Lech Kaczyński, Valdas Adamkus, Toomas 
Hendrik Ilves, Viktor Yushchenko, and Ivars Godmanis respectively) made an important gesture. Despite the ongoing military actions, they arrived in Tbilisi and took part in the rally against the conflict and the Russian aggression. It was probably the most significant gesture of support received by Georgia from its allies (vide Halbach, 2012, p. 295-312; Antonenko, 2012, p. 271-293).

The reaction of international organizations mostly involved encouraging the parties to enter into peace talks and stop military actions. NATO, the EU, the UN and the SCO believed that the solution to the crisis should be found during peace negotiations. They also did not recognize the independence of Abkhazia and South Ossetia and still treated them as the integral territory of Georgia. Despite those assurances, the status quo was different since the Russian troops were still stationed on the territory of the separatist provinces. The NATO member states together with the EU either called for withdrawal of the Russian military forces or did not comment on the situation in the South Caucasus (vide Tarkhan-Mouravi, 2014, p. 49-73). It is worth noting that the Polish diplomacy got deeply involved in the discourse on the Russian-Georgian conflict, which resulted in the initiative for the Eastern Partnership.

When it comes to the recognition of the status quo, or de facto the permanent separation of Abkhazia and South Ossetia from Georgia, the states which recognize independence of these provinces are Russia, Nicaragua, Venezuela, and Nauru. It does not change, however, the real situation of their independence. Despite their strong dependence on Russia, these republics were constituted. Also in this respect, the international community, allies and partners of Georgia have not taken any steps which could bring the autonomous territories back to Georgia. Therefore, the lack of any initiatives and passivity in the face of this problem is clearly visible.

\section{SUMMARY}

It is important to notice that the means available for Georgia during the RussianGeorgian crisis included several important agreements on strategic partnership signed with NATO, the EU, and the USA. Perhaps those partnerships were not just empty diplomatic gestures; however, the allies did not do more than standard diplomatic actions. Diplomatic notes or calling for peace talks are not too engaging. The biggest results were achieved by the EU activities. The European Union engaged most actively in the peacekeeping process and facilitated the 
Sarkozy-Medvedev agreement. However, the Georgian diplomatic activities were probably not effective enough to make the state's partners take real actions - the allies did not regard keeping the territorial integrity of Georgia as their vital interest (vide Libaridian, 2012, p. 237-256).

The most spectacular gestures included the arrival of the presidents of Poland, Lithuania, Estonia, Ukraine, and the prime minister of Latvia in Tbilisi. Despite the ongoing military activities, they supported Georgians with their presence, and at the same time, made the world's public opinion aware of the conflict on the territory of the seemingly distant South Caucasus.

The effectiveness of Georgia's external activities cannot be assessed highly. The state did not achieve any of its goals as it both lost the August war and has not regained its territorial integrity until today. It does not seem that the international community intended to do anything to restore the situation from before 2008, and Georgia itself does not have enough means to regain Abkhazia and South Ossetia. Probably, this would mean another military conflict with Russia, and maybe even a large-scale crisis. In a sense, we can now observe the consequences of the acceptance of the situation in the South Caucasus in Ukraine or Moldova.

\section{ReFERENCES:}

Allison, R. (2009). The Russian Case for Military Intervention in Georgia: International Law, Norms and Political Calculation. European Security, 18 (2), 173-200.

Antonenko, O. (2012). Toward a New Strategy for Addressing Regional Conflicts in the South Caucasus. In: F. Ismailzade, G.E. Howard (eds.), The South Caucasus 2012: Oil, Democracy and Geopolitics (p. 271-293). Washington, DC: The Jamestown Foundation.

Asmus, R.D. (2010). A Little War That Shook the World: Georgia, Russia, and the Future of the West. New York: Palgrave Macmillan.

Boesen, H., Larsen, L. (2012). The Russo-Georgian War and Beyond: Towards a European Great Power Concert. European Security, 21 (1), 102-121.

Brecher, M. (1977). Toward a Theory of International Crisis Behavior. International Studies Quarterly, 21 (1), 39-74.

Bryc, A. (2009). Rosja w XXI wieku. Gracz światowy czy koniec gry? Warszawa: Wydawnictwa Akademickie i Profesjonalne.

Bryc, A. (2011). Bezpieczeństwo w poradzieckim ładzie międzynarodowym. In: A. Bryc, A. Legucka, A. Włodkowska-Bagan (eds.), Bezpieczeństwo obszaru poradzieckiego (p. 104-120). Warszawa: Difin.

Burton, J.W. (1984). Global Conflict: The Domestic Sources of International Crisis. University of Maryland Center for Intl. 
Cohen, R. (1979). Threat Perception in International Crisis. Madison: University of Wisconsin Press.

du Plessis, S., Freytag, A., Boshoff, W. (2015). Deliberate Recovery Policy, Politics, the Economic Recovery from the International Financial Crisis. Taiwan Journal of Democracy, 11 (1), 17-36.

Fawn, R., Nalbandov, R. (2012). The Difficulties of Knowing the Start of War in the Information Age: Russia, Georgia and the War over South Ossetia, August 2008. European Security, 21 (1), 57-89.

GEOSTAT (2016). 2014 General Population Census. Retrieved from: http://geostat.ge/ cms/site_images/_files/english/population/Census_release_ENG_2016.pdf.

Government of Georgia (2005). National Security Concept of Georgia, 2005. Retrieved from: http://www.parliament.ge/files/292_880_927746_concept_en.pdf.

Halbach, U. (2012). The Southern Caucasus' Integration with NATO and EU: Current Developments and Future Perspectives. In: F. Ismailzade, G.E. Howard (eds.), The South Caucasus 2012: Oil, Democracy and Geopolitics (p. 295-312). Washington, DC: The Jamestown Foundation.

Kącka, K. (2012). Classical Theory of International Relations in View of International Security. In: K. Adamek, K. Wilczyńska (eds.), Bezpieczeństwo współczesnego świata: aspekty bezpieczeństwa narodowego (p. 131-145). Poznań: Maiuscula.

King, C. (2008). The Five-Day War Managing Moscow After the Georgia Crisis. Foreign Affairs, 87 (6), 2-11.

Lebow, R.N. (1984). Between Peace and War: The Nature of International Crisis. Baltimore \& London: Johns Hopkins University Press.

Libaridian, G. (2012). Opportunities Gained and Lost: South Caucasus Security since Independence. In: F. Ismailzade, G.E. Howard (eds.), The South Caucasus 2012: Oil, Democracy and Geopolitics (p. 237-256). Washington, DC: The Jamestown Foundation.

Materski, W. (2010). Gruzja. Warszawa: Wydawnictwo TRIO.

McClelland, C.A. (1961). The Acute International Crisis. World Politics, 14 (1), 182-204.

Mouritzen, H., Wivel, A. (2012). Explaining Foreign Policy: International Diplomacy and the Russo-Georgian War. Boulder, CO: Lynne Rienner Publishers.

North, R.C. (1963). Content Analysis: A Handbook with Applications for the Study of International Crisis. Illinois: Northwestern University Press.

Odutayo, A. (2016). Human Security and the International Refugee Crisis. Journal of Global Ethics, 12 (3), 365-379.

Parmentier, F. (2009). Normative Power, EU Preferences and Russia. Lessons from the Russian-Georgian War. European Political Economy Review, 9 (Autumn), 49-61.

Piechowiak-Lamparska, J. (2013). The Position of Georgia on the International Arena After 2008. In: J. Marszałek-Kawa (ed.), Dilemmas of Contemporary Asia. Deliberations on Politics (p. 419-436). Toruń: Adam Marszałek Publishing House.

Rondeli, A. (2014). The Russian-Georgian War and Its Implications for Georgia's State Building. In: S.F. Jones (ed.), The Making of Modern Georgia, 1918-2012: The First Georgian Republic and Its Successors (p. 35-48). London \& New York: Routledge. 
Tarkhan-Mouravi, G. (2014). Georgia's European Aspirations and the Eastern partnership. In: S.F. Jones (ed.), The Making of Modern Georgia, 1918-2012: The First Georgian Republic and Its Successors (p. 49-73). London \& New York: Routledge.

The Georgian Foreign Policy Strategy for the Years 2006-2009 (2006). Retrieved from: http://india.mfa.gov.ge/files/-Documents/strategy2006_2009.pdf.

Trenin, D. (2012). A Landscape After the Battle: The Variable Geopolitics of the South Caucasus. In: F. Ismailzade, G.E. Howard (eds.). The South Caucasus 2012: Oil, Democracy and Geopolitics (p. 257-269). Washington, DC: The Jamestown Foundation.

Tsereteli, M. (2014). Georgia as a Geographical Pivot: Past, Present, and Future. In: S.F. Jones (ed.), The Making of Modern Georgia, 1918-2012: The First Georgian Republic and Its Successors (p. 74-93). London \& New York: Routledge.

Walter, A. (2016). Open Economy Politics and International Security Dynamics: Explaining International Cooperation in Financial Crises. European Journal of International Relations, 22 (2), 289-312.

Whitman, R.G., Wolff, S. (2010). The EU as a Conflict Manager? The Case of Georgia and Its Implications. International Affairs, 86 (1), 87-107. 